\title{
Relações entre a América Latina e o Oriente Médio.
}

Ahmed Sadek El Kosheri, diretor da Faculdade de Direito da Universidade do Cairo, advogado do Mundo Árabe

\section{Ahmed Sadek El Kosheri}

Tratarei das relações entre a América Latina (distinguindo-se o papel do Brasil) e o Oriente Médio, a Africa, a Ásia e, de modo geral, as outras partes do Terceiro Mundo. Essas relações podem ser classificadas em três estágios já históricos.

\section{Os três estágios}

O primeiro estágio foi de natureza emocional, dir-se-ia influenciado pelo espírito latino. Introduziuse no sistema legal a codificação napoleônica; o futebol, a música, o samba e coisas semelhantes são apreciadas. Abrange certamente o período correspondente aos anos 30 e 40, quando o que se sabia sobre a América Latina estava misturado com famosos jogadores de futebol, os predecessores de Pelé ou Zico, e o melhor dançarino do Egito era chamado Carioca. Tal era o tipo de afinidade que existia nessa fase que termina pelo fim dos anos 40. A partir daí, o Egito, particularmente o Cairo, como sede da Liga Árabe, recebeu importante visita do governo da Venezuela que faria surpreendente revelação, porque, então, aquele país apresentava sistema muito sofisticado de trato com as companhias de operação de petróleo.

O fato marcou o segundo estágio das relações da América Latina com o Oriente Médio, época em que os xeques, reis e princípes árabes pareciam satisfeitos com os seis vinténs de royalty que lhe pagavam pelo barril de petróleo exportado. A experiência venezuelana de participação de $50 \%$ constituiu verdadeira revelação e o toque de despertar daquela parte do mundo ainda imersa no sono medieval. Foi o estopim das conferências árabes de petróleo. Daí em diante, tornar-se-iam os árabes capazes de obter recursos para o financiamento de amplos projetos econômicos e sociais de interesse próprio.

Vive-se hoje o terceiro estágio, que se caracteriza pela solidariedade e cooperação recíproca em prol da construção de um futuro viável, e em que o Brasil terá importante missão a cumprir. Esse país já atingiu certo nível de desenvolvimento e de potencialidades materiais e humanas, que se capacitou a desempenhar papel de liderança das nações do Terceiro Mundo na luta por novo modelo de desenvol- vimento econômico e social. Admite-se que uma visita de representante do Brasil ao mundo árabe seria oportuna e benéfica à área, agora tão empenhada em aplicações financeiras, seja nas exportações do Brasil para outros países, seja na exploração de amplos e variados projetos ou atividades, seja na transferência de tecnologia, seja, enfim, no que quer que o Brasil haja acumulado nos últimos anos e, a troco de boa remuneração, possa por a serviço da humanidade. O Banco Mundial já não é, pelo menos no presente momento, a única e mais importante fonte de financiamento do desenvolvimento das nações do Terceiro Mundo, pois apenas contribui com cerca de $30 \%$ do total das inversões dessa espécie na área.

\section{O Fundo Árabe para o Desenvolvimento Econômico e Social}

No mundo árabe, o pequeno Kuwait, após a independência em 1961, iniciou o chamado Fundo kuwaitiano para o Desenvolvimento Econômico e Social. O fundo partiu com menos de duas centenas de milhões de dólares, no meio árabe apenas, ao passo que hoje ostenta inversões superiores a três biIhões de dólares em torno do mundo, e se expande a qualquer país com que possa operar. Consubstancia exemplo do esforço comum pan-arábico na formação do que é presentemente o Fundo Árabe para o Desenvolvimento Econômico e Social. Este só opera nos territórios dos 22 países-membros da Liga Árabe, mas sem as restrições da rígida assistência da Europa Ocidental, isto é, se um banco de desenvolvimento francês, alemão ou inglês realiza contrato de financiamento com certo país, este país fica jungido ao comércio exterior com aquele mutuante, para ele importando matéria-prima ou materiais e dele comprando todos os suprimentos, equipamentos e serviços. Entre os árabes não existe tal problema, simplesmente porque nada produzem que possa ser vendido no mercado, exceto o petróleo bruto. Aqui é fácil competir e disputar um projeto capaz de trazer pelo menos os benefícios de participação do mercado, circunstância favorável ao Brasil se rebuscasse as listas dos projetos que estão na linha 
de abastecimento e de financiamento dos vários fundos árabes. Até agora, infelizmente, a maioria dos projetos é de natureza especial (turn-key projects), em que o suprimento de equipamentos e os serviços estão açambarcados pelas companhias ocidentais. Nada se tem contra essas companhias, porém, a fim de balancear a situação, o Terceiro Mundo deveria ter sua vez, e aqueles países mais avançados, como o Brasil, estão mesmo, dir-se-ia, na obrigação de solidarizar-se ou associar-se no sentido de alterar o modelo ou tornar mais fácil atingir o equilíbrio em termos mundiais.

Com a valorização dos preços do petróleo, acentua-se o sentimento de solidariedade entre os países árabes e cada qual procura criar seu próprio fundo. Surge, então, o Fundo Saudita, já com aplicações superiores a um bilhão de dólares, o Fundo de Abu Dabi e, por último, o Banco Islâmico de Desenvolvimento, com o capital de dois bilhões de dinares (o dinar vale pouco mais do que o dólar, pelo menos por enquanto).

Assim, todos esses recursos estão direcionados para o financiamento de projetos de desenvolvimento em outras partes do Terceiro Mundo. O Banco Islâmico de Desenvolvimento apresenta, ainda, a característica de não estar restrito aos projetos de financiamento identificados com estudos de viabilidade (ver tópico Estudo de viabilidade do texto Metodologia), mas financia, igualmente comércio exterior de países em desenvolvimento, seja quanto às necessidades de petróleo, seja quanto a requisitos de desempenho do balanço de pagamentos. Financia produtos acabados, matérias-primas, suprimentos alimentícios, qualquer coisa. A única restrição é quanto ao lucro, proibido pela lei islâmica. Para conciliar a cobrança de juros, recorre-se ao contrato de arrendamento (leasing ) - processo usado pela primeira vez na compra de uma armazenador pelo governo de Bangladesh, que só adquiriu a propriedade do bem após algum tempo, quando resgatados os recibos em poder do banco; e, em seguida, na implantação de uma fábrica da Fiat na Turquia, cujo go- verno somente adquiriu a propriedade da empresa ao fim do contrato de arrendamento.

Tais são as enormes possibilidades de financiamento existentes no meio árabe, a desafiarem a argúcia dos interessados em expandir o comércio exterior e as atividades econômicas no Brasil, o que se acredita viável, assim em relação ao desenvolvimento de projetos sofisticados, do tipo turn-key, como através dos modelos normais de contrato. No Egito, por exemplo, onde não existe indústria madeireira, todo o mobiliário é importado da Itália e uma simples sala de estar custa mais de doze mil dólares. 0 conferencista assinala que, quando morava nos Estados Unidos, mobiliou o seu apartamento com ótima madeira brasileira pela décima parte do preço levantado naquele mercado, o que não teria sido possível no Cairo, porque os brasileiros não estão lá.

\section{Os eurodólares}

Certamente uma das principais razões da atual crise econômica diz respeito ao preço do petróleo, à sombra do qual surgiu o mercado do eurodólar. $A$ economia dos países exportadores de petróleo não tem capacidade de absorver todos os recursos auferidos, que são colocados a curto prazo no mercado do eurodólar, o que, sem dúvida, não constitui solução ideal. Admite-se que a quase totalidade dos países que hoje utilizam esse mercado estaria mais interessado em investimentos a prazo longo no campo das joint-ventures e do desenvolvimento de novas atividades, que pudessem ser mais vantajosas na formação de recursos humanos, transferência e adaptação de tecnologia. Algo deve ser feito nesse sentido; existem tantos caminhos abertos à imaginação criadora e à cooperação internacional, onde se destaca, entre outros profissionais, o papel do advogado, porque as negociações entre países implicam conhecimento especializado de tradições legais, normas e processos específicos, além da aptidão de sugerir ou propor modificações nos respectivos regulamentos econômicos.

\section{A criatividade do advogado comercial}

Alberto Venâncio Filho, professor de direito comercial e advogado na área do direito societário.

$\odot$ advogado que deseja especializar-se no campo do comércio internacional deve, realmente,
Alberto Venâncio Filho

adquirir conhecimentos econômicos e financeiros e, sobretudo, desenvolver a imaginação criadora. 